\title{
A STUDY INTO SITUATED LEARNING THROUGH COMMUNITY
}

\section{LEGAL COMPANIONSHIP}

\section{Ben Waters, Canterbury Christ Church University}

Jeanette Ashton, University of Brighton ${ }^{1}$

\begin{abstract}
Against the background of the current graduate skills agenda and its considered importance in relation to a UK law degree, this article considers the value of the CLOCK Community Legal Companion scheme, a collaborative social justice project involving law students, legal services providers, third sector advice agencies and law courts based in two areas of the country namely; Canterbury and Brighton. In recent years, the UK Government has significantly cut civil legal aid in areas such as housing, family and welfare benefits, with a view to easing the strain on the deficit. These cuts have been opposed by many, including lawyers, who have raised concerns that the most vulnerable within our communities could be left unrepresented in court and as a consequence an undue burden placed on our civil justice system. CLOCK therefore provides an opportunity for those within our communities who are caught in the so-called 'justice gap', to gain support and guidance from law students when they attend court unrepresented. The findings of a small-scale research project into the perceived benefits of Community Legal Companionship, conducted at two UK law schools; Canterbury Christ Church University and the University of
\end{abstract}

\footnotetext{
${ }^{1}$ Ben Waters is Senior Lecturer in Law at Canterbury Christ Church University, and Jeanette Ashton is Senior Lecturer in Law at The University of Brighton,
} 
Brighton, indicate that the socio-legal experiential learning opportunities for undergraduate law students presented by such initiatives, are also valuable in terms of legal skills acquisition. The research shows that the scheme not only enables law students to use their legal knowledge for the benefit of their local community, but also through analysis of their own perceptions, demonstrates how such a community-based project can provide undergraduate law students with valuable employability skills. Experiences of setting up a Community Legal Companion scheme, together with an overview of how the scheme operates in the Canterbury and Brighton County Courts, as well as students' reflections of participating as Community Legal Companions drawn from the empirical qualitative research, are evaluated in this article.

\section{INTRODUCTION}

The number of self-represented litigants or litigants in person (“LiPs") arriving at court has risen steadily for over a decade. Interestingly, the rise in the LiP has coincided with implementation of the Access to Justice Act 1999, introduced to promote just that "access to justice". The reality however is that through various government initiatives and further legislation, most notably the Legal Aid Sentencing \& Protection of Offenders Act 2012 or LASPO, aspects of the 'Welfare State' have been systematically dismantled. This has included the introduction of competitive price tendering for legal aid contracts and the incremental withdrawal of legal aid for many areas of legal advice and assistance within civil justice and perhaps most notably private family law. 
The reduction in local authority funding of the advice sector, the adverse impact on many people due to the prevailing economic climate, the rising cost of legal services and the reduction in court resources, has meant that a whole raft of UK citizens has been 'marginalised' and now fall within what is commonly termed the 'justice gap'. As highlighted in a 2017 Law Society of England and Wales report this has given rise to an increased number of LiPs who have been unable to either afford legal advice or indeed have the awareness to be able to access the few legal services still available which provide pro bono or limited fixed fee advice and assistance. ${ }^{2}$ Reports from 2016 show that of all the cases defended in the county court, both the claimant and the defendant were legally represented in just $56 \%$ of them. Neither had representation in roughly $18 \%$ and $26 \%$ of cases were conducted with just the claimant being represented. Consequently, of all the proceedings commenced in the county court during $2016,44 \%$ of those cases involved at least one party who was a self-represented litigant. ${ }^{3}$ Whilst reliable pre-LASPO data on Litigants in Person are scarce, most available data concern LiPs in the family courts, although the National Audit Office (NAO) has claimed that the increase in LiPs has also been evident in the civil courts

\footnotetext{
'Law Society of England and Wales "Access Denied? LASPO 4 years on: a Law Society review" https://www.lawsociety.org.uk/support-services/research-trends/laspo-4-years-on/ (accessed on 28.12.17).

${ }^{3}$ National Statistics: Civil justice statistics quarterly, available at: https://www.gov.uk/government/statistics/civil-justice-statistics-quarterly- (accessed on 13.05.17).
} 
as well. ${ }^{4}$ The NAO observed that since the implementation of the government's 2012 reforms, there had been increases in the numbers of cases in the family courts where either or both parties did not have legal representation. This has included a $22 \%$ increase in cases involving contact with children (Children Act private law matters) in which neither party was legally represented, a 30\% increase across all family court cases (including those that remain eligible for civil legal aid) in which neither party had legal representation and $80 \%$ of all family court cases starting in the JanuaryMarch quarter of 2013-14 had at least one party who did not have legal representation. ${ }^{5}$

Judicial concern about the strain this is placing upon the civil justice system, particularly in the area of private family law, is evident. ${ }^{6}$ Initiatives have therefore been explored and implemented by the Ministry of Justice through investment in Personal Support Units (PSU), LawWorks, Law for Life and the Royal Courts of Justice

\footnotetext{
${ }^{4}$ National Audit Office, Implementing Reforms to Civil Legal Aid, 20 November 2014, HC 784 2014-15: p.15. in Grimwood G.G., House of Commons Briefing Paper Number 07113, 14 January 2016, Litigants In Person: The Rise Of The Self-Represented Litigant In Civil And Family Cases, p.6.

${ }^{5}$ Ibid.

${ }^{6}$ See the report of the proceedings of the Parliamentary Select Committee on Justice printed on 04.03.15 entitled Impact of changes to civil legal aid under Part 1 of the Legal Aid, Sentencing and Punishment of Offenders Act 2012. In this report representatives of the Family Justice Council reported to the Committee that: "The judicial members of the FJC have all experienced a much greater pressure upon HMCTS both in terms of the administrative and judicial staff. Unwilling litigants in person take more time and resource from the courts, both administrative and judicial, CAFCASS and other supporting organisations". The Parliamentary Report of these proceedings is available at https://publications.parliament.uk/pa/cm201415/cmselect/cmjust/311/31109.htm (Accessed on 04.01.18). See also; The Law Society's Report entitled Access Denied? LASPO Four Years On: A Law Society Review, June 2017, available at www.lawsociety.org.uk p.2. (accessed on 04.01.18).
} 
Advice Bureau, in an attempt to remedy what is undoubtedly a growing problem for the civil justice system. ${ }^{7}$ Due to closure of many charitable advice services and law centres during the recent period of austerity (there are now only 46 law centres in the UK compared with more than 60 , twenty years ago), ${ }^{8}$ universities have started to fill the space once occupied by legal advice services, which traditionally provided advice and assistance to those most in need and at no cost to the end-user. In 2016 Nottingham Law School's Legal Advice Centre become a teaching law firm after being granted Alternative Business Structure ("ABS") status by the Solicitors Regulation Authority (SRA), the first of its kind in a UK university. ${ }^{9}$

CLOCK is a project designed, among other things, to give keen law students the opportunity to gain valuable employability skills by acting as Community Legal Companions ("CLCs”) at local county courts. ${ }^{10}$ CLOCK stands for Community Legal Outreach Collaboration Keele and was initiated by Keele law school in 2012 following the introduction of LASPO and the reduction of legal aid, which has resulted in the growing numbers of people arriving at court without representation. ${ }^{11}$ The project

\footnotetext{
7 Ministry of Justice, "More Support for Couples and Parents", available at https:/www.gov.uk/government/news/more-support-for-separating-couples-and-parents, in McKeown, P., \& Morse, S. (2015), Litigants in Person: Is There a Role for Higher Education? Edited by Richard Owen. The Law Teacher, 49(1), 122-129.

${ }^{8}$ Law Centres Network, available at http://www.lawcentres.org.uk/, (accessed on 13.05.17).

9See: https://www.ntu.ac.uk/about-us/news/news-articles/2015/nottingham-law-school-granted-abslicence (accessed on 13.05.17).

10 Supra, McKeown, P., \& Morse, S., note 7, at 123.

${ }^{11}$ Full details of the CLOCK project at Keele are available at https://clock.uk.net/ (accessed on 13.05.17).
} 
enables law students to become trained up as CLCs to provide signposting as well as other guidance and support to those in need and who attend court unrepresented.

\section{ACCESS TO JUSTICE AND LASPO: FORMATION OF THE CLOCK SCHEME}

The CLOCK legal companion scheme was developed by Dr Jane Krishnadas within Keele University School of Law ("Keele") following her work with a local domestic violence organisation 'Voices of Experience'. Through this work it was apparent that, particularly post-LASPO, victims of domestic violence often find themselves navigating a number of legal pathways to resolve for example child arrangements and housing needs, often alongside criminal proceedings. The relationship with 'Voices of Experience' led to requests for assistance in court for litigants who were understandably daunted by the prospect of their forthcoming proceedings.

Keele set up a pilot McKenzie Friend scheme, following which Dr Krishnadas attended an address delivered by the then President of the Law Society, Lucy Scott Moncrieff, at the North Staffordshire Regional meeting on the challenges of meeting unmet community legal needs in the wake of LASPO. Representatives from the local Law Society, Citizens Advice Bureau and Keele considered the impact of LASPO and the so-called 'justice gap' on the community, particularly important in Stoke-onTrent. ${ }^{12}$ They considered the inevitable increased pressures on third sector

\footnotetext{
${ }_{12}$ One of 20 local authority districts with the highest proportion of neighbourhoods in the most
} deprived 10\% of neighbourhoods nationally on the Index of Multiple Deprivation 2010 and 2015 
organisations and the sustainability of the city's high street law firms, many of which had worked under legal aid contracts providing advice on family and housing law matters, areas most affected by the LASPO reforms.

The CLOCK legal companion scheme was developed from that meeting, drawing on the McKenzie Friend role, but crucially developing it specifically for law students. ${ }^{13}$ Although wider discussion of the McKenzie Friend role is beyond the scope of this article, concern about the increased use of fee-paying McKenzie Friends has been expressed in the legal profession on a number of occasions, and it may be that the role of the law student CLC will become increasingly important. ${ }^{14}$ The CLC role is to provide legal information, not legal advice, to assist litigants with form-filling and arranging papers and perhaps most importantly, to signpost litigants to third sector organisations and legal providers who may be able to provide services under a legal aid contract or fixed fee or unbundled services. Where this is not possible, the CLC can accompany the litigant into court proceedings under McKenzie Friend principles, to provide moral support and take notes for them. As seen in the discussion of the

https://www.gov.uk/government/statistics/english-indices-of-deprivation-2010-technical-report, https://www.gov.uk/government/statistics/english-indices-of-deprivation-2015 (accessed on 03.07.17).

${ }^{13}$ For discussion of the development of the 'McKenzie friend' role which provides support and assistance to unrepresented litigants in court, and the growing concern regarding the proliferation of 'professional', fee-charging McKenzie friends and the variation in support provided, see Moore, S. and Newbury, A. Legal Aid in Crisis: Assessing the Impact of Reform, (Policy Press, 2017), pp 50-53.

${ }^{14}$ For further discussion on this see: https://www.solicitorsjournal.com/news/legalprofession/barristers/25667/bar-council-mckenzie-friends-should-not-be-allowed-charge-leg (accessed on 10.07.17). 
study findings to follow, the CLC needs to be organised, professional, able to react quickly and calmly under pressure, and to utilise key communication skills such as listening and empathy in order to build a good rapport with the litigant. There is a recognition however that although the CLCs provide invaluable assistance and support, the goal is to secure professional advice even in these challenging times. CLOCK National, based at Keele, operates a web-based administrative system (the clock.uk.net national dataset) which is available for recording the information gathered from the service users, the aim being that this data will inform policy on a national level. ${ }^{15}$

CLOCK was born out of a collaborative discussion at the meeting mentioned above, looking at community need, and a collaborative, multi-agency approach is key to its ethos. Law schools, charitable organisations and legal service providers work together to provide a holistic service for litigants which, Moore and Newbury suggest;

Perhaps highlights the key role that family law solicitors played, over and above purely being purveyors of legal advice, in the amount of both emotional and practical support that they were giving to their clients. ${ }^{16}$

\footnotetext{
${ }^{15}$ E.g. CLOCK submitted evidence to the Bach Commission on Access to Justice, which published its final report in September 2017, available at: http://www.fabians.org.uk/wpcontent/uploads/2017/09/Bach-Commission_Right-to-Justice-Report-WEB.pdf (accessed on 28.12.17). 16 Supra, note 13, Moore, S. \& Newbury, A., p52.
} 
Since its inception at Keele, the scheme has grown and now includes a number of universities with CLCs volunteering at courts around the country. All law students at these universities participating as CLCs are monitored and insured by their respective universities. They are required to undertake DBS checks and are bound by the CLOCK confidentiality agreement. Companions from each institution commit to a certain number of court based help desk hours agreed by their respective institutions during term-time. Outside of term-time there is a reduced service, where the CLCs who live locally, signpost and arrange appointments depending on availability. CLCs are bound to report all community legal companion activities. It is important to recognise that CLCs do not provide advice and service users are made aware of this from the outset. A key part of legal companion role is signposting, thus being able to develop close links with legal and third sector partners is essential.

\section{PEDAGOGICAL CONTEXT}

\section{Experiential Learning and the Skills Agenda}

In December 2006 the government commissioned the Leitch Review to identify the UK's optimal skills mix in 2020 to maximise economic growth, productivity and social justice, and to consider the policy implications of achieving the level of change required. One of its recommendations was to widen the drive to improve the UK's high skills to encompass the whole working-age population, including preparing 
young adults for their working lives. ${ }^{17}$ High skills can be understood in different national contexts such as quality of employment, training opportunities, and the abilities of individual. ${ }^{18}$ It is argued therefore that legal education provides rigorous and academically challenging 'training' to produce highly skilled students in order to prepare them for high quality (well-paid) employment.

The most recent review of legal education, the Legal Education and Training Review (LETR) published in 2013, made suggestions about encouraging law schools to embed practice-skills within the legal education curriculum. The review committee acknowledged the growing levels of interest and activity around work-based learning, apprenticeships, and the re-design of CPD points to a renewed interest in the workplace as a site of learning and source of professional competence. The committee considered this a matter of some relevance to the LETR in determining focus and direction of travel. ${ }^{19}$ McKeown and Morse argue that students are often enthusiastic about engaging in clinical activities and, linked to this make the point that in a

\footnotetext{
${ }^{17}$ The Leitch Review p.143, published in December 2006 is available at http://www.delni.gov.uk/leitch_finalreport051206[1]-2.pdf (accessed on 08.06.17).

${ }^{18}$ Brown, P, Green, A, Lauder, H, High Skills: Globalization, Competitiveness, and Skill Formation: Globalization, Competitiveness, and Skill Formation, (Oxford University Press, 2001).

${ }_{19}$ Webb, J., Ching, J., Maharg, P. and Sherr, A., Legal Education and Training Review (LETR), Setting Standards: The Future of Legal Services Education and Training Regulation in England and Wales (London: Legal Education and Training Review, 2013). Available at http://www.letr.org.uk/thereport/index.html (accessed on 26.05.17).
} 
competitive market, it is important that universities offer courses and extra-curricular activities, which are appealing and relevant to prospective students. ${ }^{20}$

The development of a global clinical legal education movement has been well documented by many commentators with an interest in the field and none better so than by Bloch, who acknowledges that the UK's engagement with clinic has been distinctive because of the educational, professional and social context that has shaped the process of lawyer education and training. ${ }^{21}$ It is fair to say that clinical legal education ("CLE"), in some form, is progressively becoming a more regular component of undergraduate legal studies in the UK, particularly as the number of law schools has grown. ${ }^{22}$

Duncan argues for CLE at undergraduate level of legal education and his views can be applied quite appropriately to the CLOCK project and the experiential learning opportunities available to students when providing assistance to those who are either ineligible for legal aid or cannot afford to pay for legal advice:

It provides the most powerful experience of the real context in which the law operates; it is the most effective way of developing transferable and specific professional skills and it provides a sound basis for ethical practice. It works most

\footnotetext{
20 Supra, note 7, McKeown, P., \& Morse, S., p. 128.

${ }^{21}$ Bloch, F.S. (ed.), The Global Clinical Movement: Educating Lawyers for Social Justice (New York: Oxford University Press, 2001), p.7.

22 Supra, note 7, McKeown, P., \& Morse, S., p. 128. See also Carney, D., Dignan, F., Grimes, R., Kelly, G., \& Parker, R. (2014), LawWorks Law Schools Pro Bono and Clinic Report, (2014, LexisNexis UK).
} 
effectively when reinforced with built-in requirements for reflection and approaches to curriculum design which expect students to take some responsibility for their own learning. This experience should precede the training contract or pupillage. In designing courses which meet these objectives we can also help with the provision of legal services to those who cannot afford to pay for them. ${ }^{23}$

It is arguable that the CLC role is just as powerful in terms of experience of the real context in which law operates. Students immerse themselves in the court environment and have 'hands on' contact with court procedure and the operation of court process as a means of dispute resolution. The students are not directly supervised when at court, they have to think for themselves, respond to situations as they arise and take initiative as well as responsibility for their actions. In so doing these law students acquire valuable transferable skills. The role requires recognition of a CLC's ethical boundaries in not providing advice. Students assist service users without consultation which otherwise would be the case in a formal advice clinic environment. These are all things which the student can reflect upon. In undertaking these tasks at undergraduate level such law students are preparing themselves for the world of professional employment, whilst at the same time helping to provide the kind of legal

\footnotetext{
${ }^{23}$ Duncan N, Ethical Practice and Clinical Legal Education, 7 Int'l J. Clinical Legal Educ. 7 2005, 7-19, p.19.
} 
services which many service users would have received from legal services providers before the withdrawal of legal aid.

The growing interest with which UK law schools and those abroad are treating dispute resolution, alternative dispute resolution ("ADR") and its teaching, ${ }^{24}$ provides a perfect opportunity for students to work closely with people who are in dispute and apply practically the theory they have learnt in the classroom. Any court proceedings arise from some kind of dispute; whether it be a tenant questioning a landlord's claim for rent arrears; a relationship breakdown involving domestic violence and/or children's arrangements or a consumer contract dispute between a retailer and customer. All casework with which CLCs provide assistance, involves court service users seeking a civil remedy, which will ultimately achieve a resolution to their dispute in some way or another. Research undertaken by the authors at University of Brighton and Canterbury Christ Church University (the authors' study) indicates that students recognise the importance of the role in placing their studies in context. An example of this provided by one participant in the study is as follows:

"Currently I am studying family law... and have found that a lot of family cases have been assisted by the CLOCK scheme. This has allowed me to view the theoretical teachings of this module in practice"

\footnotetext{
${ }^{24}$ Waters B.D., The Importance Of Teaching Dispute Resolution in a Twenty-First-Century Law School The Law Teacher 51, 2, 2017, pp.1 and 8.
} 
There are also clear links with many aspects of the legal education curriculum (at both undergraduate and postgraduate level) and at undergraduate level, this includes those foundational and/or core modules such as; English legal system, law of tort, property law, equity and trusts and some optional modules such as family law and intellectual property law. Teaching dispute resolution as a defined subject contextualises much of what student CLCs learn in such a module, it grounds the subject discipline theory and provides the opportunity for practical skills acquisition. ${ }^{25}$ Even better, linking assessment to the CLC role will enable students to gain academic credit for their work-based learning.

\section{Employability}

From the early part of the millennium, UK higher education institutions ("HEIs") have been increasingly charged with promoting graduate employability. ${ }^{26}$ This coincided with New Labour's neo-liberal third way education policy drive to create a more educated nation, which in turn proposed to contribute directly to the development and enhancement of the so called 'knowledge economy' ${ }^{27}$ For HEI's, employability statistics are becoming increasingly more important and their performances are

\footnotetext{
${ }^{25} \mathrm{Ibid}, 227-246$.

${ }^{26}$ Knight, P. T., \& Yorke, M. (2003). Employability and Good Learning in Higher Education. Teaching in Higher education, 8(1), p.3.

27 Waters, B. (2013). Widening Participation in Higher Education: The Legacy for Legal Education. The Law Teacher, 47(2), 261-269.
} 
monitored $^{28}$ with the performance indicators having implications for league table positioning.

The LETR recognised that from the student perspective, competition generally for recruitment to the legal profession is likely to remain fierce for the remainder of the decade. The review committee considered that for employers it is likely to remain a buyer's market in the short-to-medium term, at least for those in the larger firms and in chambers generally, though inter-professional competition for those traditionally perceived to be the 'best' candidates is likely to continue to be strong, particularly in the commercial sphere. ${ }^{29}$ In 2015 the Solicitors Regulation Authority announced its plans for wholesale changes to the qualification requirements for solicitors and in June 2017 the Solicitors Qualification (SQE) Draft Assessment Specification was published. This document emphasises the requirement to demonstrate a number of practical competencies at Stage 2 of the SQE, including; client interviewing, advocacy/oral communication, case and matter analysis, legal research and legal drafting. Elements of all these competencies are present within the CLC role. ${ }^{30}$

There is an arguable requirement for those students wishing to enter either branch of the legal profession to enhance their curriculum vitae with extra-curricular

\footnotetext{
${ }^{28}$ See the Higher Education Statistics Agency (HESA) and the employment indicator, which is based on the Destinations of Leavers in Higher Education (DLHE) survey https://www.hesa.ac.uk/data-andanalysis/performance-indicators/employment (accessed on 30. 05.17).

${ }_{29}$ Supra, note 19, Webb, J., Ching, J., Maharg, P. and Sherr, A., paragraph 3.154.

${ }^{30}$ The SRA's draft Assessment Specification sets out the indicative design and content of the SQE and is available at https://www.sra.org.uk/sra/policy/sqe/research-reports.page (accessed on 10.01.18).
} 
engagement, which can then give them an edge in the job application process. Community Legal Companion support provides the kind of graduate profile enhancement which is beneficial in this regard. The authors' research indicates that students who have been involved with the CLOCK project and lucky enough to be invited for interview (for training contract or pupillage) gain an advantage. Some students report that interest had been taken in the role at interview and whilst it cannot be claimed that such experience is the difference between being offered a job or not, it enhances employment prospects immeasurably. One CLC participating in the study commented that they had already experienced a benefit;

"I've already been asked about [CLOCK] at interviews and it is a very interesting talking point. Additionally, it enables us to understand the court process better than fellow law students who are not part of the scheme."

Whilst recognising the challenges presented to university law schools in attempting to make work experience widely available as one way to redress the problems of differential access to the legal profession, Francis recognises that student experiences can be a powerful learning and teaching resource. ${ }^{31}$ The authors' research suggests that a number of students acting as Companions and who intend to to pursue careers as either solicitors or barristers recognise this:

\footnotetext{
${ }^{31}$ Light, G. \& Cox, R. Learning and Teaching in Higher Education: The Reflective Professional (2001) 79, in Francis, A. (2015). Legal Education, Social Mobility, and Employability: Possible Selves, Curriculum Intervention, and the Role of Legal Work Experience. Journal of Law and Society, 42(2), 173-201.
} 
"I want to be a lawyer, I am currently applying for LPCs and having the companion scheme on my CV will be invaluable."

Another commented:

"I would like to have a career at the Bar. CLOCK will support this by giving me a great opportunity and experience which will help me to stand out for future employers, scholarship boards and law schools."

From their qualitative study into perceptions of the role clinical education plays in influencing employability, Alexander and Boothby found that alumni who had participated in CLE were overwhelmingly positive about their experience and continued to reflect on what they had learned there. ${ }^{32}$ They also found that the diversity of experiences on entering the legal profession was highlighted by this group, including differing levels of support and supervision. The study also questioned employers who revealed that business awareness was considered to be important from their perspective, together with skills such as communication and selfmanagement, although employers emphasised communication beyond conventional written and oral skills, to include interpersonal skills as being key. These are the kind of skills which are acquired by CLCs through participation in the CLOCK initiative

\footnotetext{
${ }^{32}$ Alexander, J., \& Boothby, C. (2016). Perceptions of the Impact of clinical legal education on employability. SRHE International Conference on Research into Higher Education, December 7-9 2016
} 
and the authors' study reveals that students generally consider their skills are enhanced. For example, one participant revealed that;

"[Being a Companion has] helped me to apply skills I already have and to use them in a novel situation e.g. when a litigant comes into the room, you have no advance notice of what s/he will need help with, and it's essential to be calm, inspire confidence, listen and fully grasp the issues before jumping in."

Competition in the North American legal employment market is equally as fierce. In the USA research was undertaken into employment competencies and those acquired through law clinic experience. Hamilton reviewed a number of studies on the competencies employers want, and his meta-analysis offers this observation on the employment market for students:

In this challenging market for employment, a law student can differentiate herself from other graduates by demonstrating to legal employers that the student both understands the core competencies that legal employers and clients want and is implementing a plan to develop these competencies, including an ability to demonstrate that the student has experience with these competencies. ${ }^{33}$

\footnotetext{
${ }^{33}$ Hamilton N., Law Firm Competency Models \& Student Professional Success: Building on a Foundation of Professional Formation/Professionalism, 11 U. ST. Thomas L.J. 6, 26 (2013), in Kuehn, R. R. (2015), Measuring Clinical Legal Education's Employment Outcomes. Wis. L. Rev., 2015, 645-537., p. 663.
} 
The competencies which are required for legal practice in England and Wales are specifically expressed in the forthcoming SQE requirements mentioned earlier. The way in which these competencies are enhanced through different kinds of work experience initiatives is acknowledged through research undertaken by Ching and Henderson. ${ }^{34}$ Whilst not considered by the researchers and authors of that report (CLOCK was its infancy at the time when the data was gathered), the CLC role should also be included in the category of such 'work experience' type activities. An example of how participants in the authors' Canterbury/Brighton study consider that their role as a CLC has contributed to the development of some of these competencies is displayed by this CLC's comment:

"[N]ot only does it look good on your CV, but CLOCK has helped develop key skills for employment: client contact/customer care; organisational skills; professionalism."

The key skills mentioned by this CLC broadly relate to the kind of skills which indicate competence as recognised by the SRA, and which form part of the proposed assessment approach of the SQE. ${ }^{35}$

\footnotetext{
${ }^{34}$ See the Report of Ching, J. and Henderson, P. Pre-qualification Work Experience in Professional Legal Education, (August 2016) and commissioned as part of the SRA's Training for Tomorrow project, available at: https://www.sra.org.uk/sra/policy/training-for-tomorrow/resources/workplacelearning.page (accessed on 10.01.18).

${ }^{35}$ See supra, note 30 .
} 


\section{Communities of Practice}

The concept of a community of practice is a group of people who share a craft and/or a profession and was first proposed by cognitive anthropologist Jean Lave and educational theorist Etienne Wenger. ${ }^{36}$ Wenger then significantly developed the concept by presenting a theory of learning that starts with the assumption that engagement in social practice is the fundamental process by which we get to know what we know and by which we become who we are. ${ }^{37}$

In the sphere of legal education it is closely associated with professional ethics and an appreciation that aspirational lawyers will be entering a 'community of practice' when acting as legal executives, paralegals, solicitors and barristers. Baron and Corbin argue for a recognised need for law students to 'be professional and in turn act like professionals'. They refer to the Carnegie Report which looked into North American legal education and observe that the Report argues that law schools can take specific, concrete actions likely to encourage law students to appreciate that they will be entering the legal profession's 'community of practice'. This has relevance not only for Australia but also for other common law jurisdictions including the UK. ${ }^{38}$

\footnotetext{
${ }^{36}$ Lave, J. (1991). Situating learning in communities of practice, Perspectives on socially shared cognition, $2,63-82$.

37 Wenger, E., Communities of Practice: Learning, Meaning and Identity, (Cambridge: Cambridge University Press, 1999).

${ }^{38}$ Baron P., \& Corbin L., Thinking like a lawyer/acting like a professional: Communities of practice as a means of challenging orthodox legal education, The Law Teacher, 46:2, 100-119, pp.100-101.
} 
Situational or situated learning presents real time experience of ethical dilemmas. Dewey saw this as exposure to the 'problematic' that leads to and is the organiser for learning. ${ }^{39}$ Students need to also have their moral sensitivities challenged to recognise that there are often "relevant others" who may be affected by legal actions. ${ }^{40}$ The authors' research reveals that Legal Companionship presents perfect opportunities for students to step out of their 'comfort zone' and have exposure the real life situations. For some students this has been challenging, as shown by these CLCs' comments:

"At times I have felt overwhelmed by having many service users come in and having to deal with them on my own. It's also been tough to deal with areas of law that I am not familiar with..."

And,

"At times it can be intimidating as a law student in providing legal assistance when the service user has a case concerning an area of law you are not fully confident in dealing with or haven't previously looked into."

It can be argued that the CLC role forms part of a 'community of practice'. Companions are introduced to professional ethics and in the context of the CLC role, this requires students to recognise that they cannot provide legal advice and this can test their ethical boundaries.

\footnotetext{
${ }^{39}$ Dewey, J. Experience and Education, (Simon and Schuster, 2007).

${ }^{40}$ Ibid p.104; and Hazard, G.C., Jr, “Dimensions of Ethical Responsibility: Relevant Others" (1992-1993) 54(4) University of Pittsburgh Law Review 965-977, at pp.969-971, in Baron P., \& Corbin.
} 
Constructionist theory is applicable here and theorists such as Savery and Duffy suggest that knowledge evolves through social negotiation and through the evaluation of the viability of individual understandings. They argue that the social environment is critical to the development of our understanding as well as to the development of the body of propositions we call knowledge. ${ }^{41}$

On ethics, Duncan argues;

those dealing with real cases within their educational experience will perforce have come into contact with the ethical issues that are endemic in legal practice and will not have been able to evade them. They will have been under a duty to take decisions and actions.....Furthermore, their experience will have addressed ethical issues in a way hard to achieve without clinical experience. ${ }^{42}$

\section{Community Engagement}

Another area to consider is the value of public service community engagement in assisting community members gaining access to justice. As well as an inherent sense of philanthropy associated with voluntary work within the community, it could also be a vital component if some voluntary services are to survive. The

\footnotetext{
${ }^{41}$ Savery J. R., and Duffy T. M., in Wilson B. G., (1998), Constructivist Learning Environments: Case Studies in Instructional Design, (Englewood Cliffs, New Jersey, Educational Technology Publications), p.136.

${ }^{42}$ Supra, note 20, p.16.
} 
authors' study indicated that students recognise the valuable community role they are playing as CLCs, this was evidenced by the responses provided by these CLCs who participated in the study:

"I wanted to participate because the programme seemed like a great opportunity to gain work experience while giving back to the community."

And,

"I feel like the scheme really helps the community and it is a way that I can feel like I am helping as well as it improving my studies."

Since 2010, successive Conservative-led governments have been keen to establish and promote their "Big Society" agenda in the UK. Whilst this seemingly embraces enterprising proposals to reinvigorate communities through greater autonomy, the initiative has in reality been devastating for some services situated in the voluntary sector that have traditionally relied on funding streams from inter alia local authorities, streams which during the current austerity era have all but dried up. ${ }^{43}$

\footnotetext{
${ }^{43}$ See Future Funding Outlook for Councils 2019/20 Interim 2015 update, available at: https://www.local.gov.uk/sites/default/files/documents/future-funding-outlook-co-18b.pdf (accessed 28.12.17).
} 


\section{CLOCK IN KENT \& SUSSEX: SETTING UP AND PRACTICAL ISSUES}

\section{Setting Up}

After successfully establishing the scheme in some of the Staffordshire courts, the CLOCK franchise was adopted by a few law schools across the country. In addition to Keele, there are now 8 universities which operate a CLOCK help desk at their local county court run by law students, including; University of Brighton, University of Sussex, University of Wolverhampton, Birmingham City University, Salford University, Liverpool John Moores University, Staffordshire University and Canterbury Christ Church University with Open Justice at the Open University, University of Leicester and Lancaster University having recently joined.

For the purpose of this paper, experiences establishing the schemes in Brighton (University of Brighton and University of Sussex) and Canterbury Christ Church University will be focused upon. Being aware of some of the work done by the Civil Justice Council, the judiciary, the Low Commission and others in connection with the growing numbers of Litigants in Person, The Master of the Rolls (then LJ Dyson) and Head of Civil Justice asked Mrs Justice Asplin to take on a judicial coordinating role in relation to LiPs. A national network of nominated judges for LiPs was established ${ }^{44}$ and the initiative in the southeast region was therefore initially driven and by Kent

\footnotetext{
${ }^{44}$ See The Civil Justice Council's summary of the Third National Forum on Access to Justice for Litigants in Person, November 2014, available at: https://www.judiciary.gov.uk/wpcontent/uploads/2011/03/web-summary-of-lip-forum-2014.pdf (accessed on 11.01.18).
} 
and Sussex family judges. In Brighton, the family court judges specifically asked for the introduction of CLOCK and HHJ Mary Lazarus based at Medway County Court, the nominated LiP judge for the Kent area, was supportive of approaches made through Canterbury, to establish CLOCK in the Canterbury Law Courts.

Both Canterbury Christ Church and the University of Brighton and the University of Sussex coordinated meetings in their respective areas attended by potential stakeholders including the judiciary, court staff, and representatives from the legal services community and third sector agencies. The initiatives gained momentum and the help desks in these courts became operational in January 2016 (Brighton) and May 2016 (Canterbury). Staffing of these desks requires the assistance of willing student CLCs and through training programmes adapted from the model designed by Keele, CLCs were trained up by the CLOCK partners and academic leads over a five day period. Sussex and Brighton collaborated and Canterbury Christ Church conducted their own training. Training varies according to the needs of the communities in the various CLOCK hubs, but will typically include training by local law firms on family law issues and court procedure and by local third sector organisations on issues which litigants may experience such as domestic abuse, housing and debt problems. Training also includes a visit to the local court with input from the court staff and judges. The academic leads provide training on legal ethics and experienced CLCs assist with simulations based on their experience at court so that new CLCs feel as prepared as possible before embarking on the role. 


\section{The Scheme in Operation}

Structures were put into place including a rota and a reporting system. A collaborative approach was adopted in Sussex where law students from both Sussex and Brighton universities were recruited for training. The training was delivered in Canterbury and Brighton by members of court staff, representatives from the local legal service community (law firms and barristers chambers) and third sector agencies who are part of the collaborative partner providers.

Once trained the CLCs are allocated to the court rota by choosing their own slots. Service users arrive at the Court Help Desk through a number of different routes including; phone calls, applications via the CLOCK Admin system which in turn alerts the Companion on help desk duty via email and in Brighton there is a separate, dedicated CLOCK email service, monitored by CLCs, through which applicants can access signposting and arrange appointments as required. Partner providers also refer service users. Some who attend court for a hearing are directed to the help desk by court staff. Brighton offers a drop-in service during term-time for those who need guidance and signposting recommendations. Once it is established by the CLCs that a service user requires assistance, the service user will sign a 'Community Care Letter' which sets out the limitations of the service and most importantly, that the CLCs do not provide legal advice. It may be at that stage that the service user is signposted to a legal aid franchised firm, affordable fixed fee or pro bono service e.g. Kent Law Clinic in Canterbury and the Sussex Family Law Clinic in Brighton. Partner 
organisations most commonly include legal aid providers for private family law, and where applicable, those legal service providers who are prepared to give fixed fee legal advice, mediation providers and charitable support services.

\section{THE BRIGHTON AND CANTERBURY RESEARCH STUDY}

The small-scale qualitative research study undertaken by the authors at the University of Brighton and Canterbury Christ Church University, was designed to determine the value of the CLOCK Companionship role for law students in terms of skills acquisition, community involvement and employability enhancement. The intention was to find out what such a social justice project says about experiential learning and what it can do for developing law students' employability and their readiness for the world of work. All CLCs from the University of Brighton and Canterbury Christ Church University were invited to participate. They were asked to complete a free text questionnaire ("Questionnaire 1") after the training prior to commencing the role and then a free text follow up questionnaire after the three-month pilot ("Questionnaire 2"). Responses were explored further in a focus group at each university. In Brighton, there were 11 responses to Questionnaire 1 from a possible 16 and in Canterbury 32 responses from 46, giving a combined response rate of $69 \%$. In Brighton, there were 10 responses to Questionnaire 2 from a possible 14 and in Canterbury 23 responses from a possible 46, giving a combined response rate of $55 \%$. In Brighton, 6 undergraduate CLCs took part in the focus group and in Canterbury 
2.45 Acknowledged limitations of the study include the small sample size and recognition that the students who participated were likely to be the most motivated of the group, which may impact on the transferability of the findings. ${ }^{46}$

\section{Methodology}

Following ethics approval, in order to gather the data for this empirical research study, a purposive, mixed-method sampling approach was utilised, consisting of questionnaires and focus groups. ${ }^{47}$

Questionnaire 1 asked students about their motivations for applying for the scheme; whether they had any previous experience of volunteering; their expectations of training and whether the training had met those expectations; whether they had any concerns about the role; whether they thought volunteering as CLCs would support their academic studies and finally they were asked about their career aspirations and whether they thought volunteering as a CLC would support those plans. Questionnaire 2 asked about the assistance they had provided; what they had most and least enjoyed about being a CLC; whether they thought the training had prepared them for the role and anything that could be improved for future cohorts; whether

\footnotetext{
${ }^{45}$ The CLOCK project started later in the academic year at Canterbury Christ Church which meant that the timing of the focus group could not be arranged until after the exam period, which is likely to account for the low number of participants.

${ }^{46}$ Denscombe, M. The Good Research Guide for small-scale social research projects (Oxford, Oxford

University Press, 2007), p.299.

${ }^{47}$ Ibid pp. 178-183.
} 
they felt volunteering as a CLC had supported their academic studies; whether the role had helped them to develop key skills and whether they felt that being part of the CLOCK project could support their future employability. In the focus groups, the findings from the questionnaires were explored in more depth.

\section{Research Findings: ${ }^{48}$}

The data from Canterbury and Brighton produced similar themes with no discernible difference between the two cohorts. The data is discussed in more detail below but the key findings were as follows:

\section{Motivation for volunteering and perceived benefits}

Questionnaire 1, completed after the training but before commencing as CLCs, revealed gaining experience and enhanced employability as the biggest motivating factor, with helping the local community closely behind. Perceived benefits were CV enhancement and supporting their career plans alongside the development of key skills and support for academic studies.

Questionnaire 2, completed after three months in the role, and the follow up focus groups, gave the students the opportunity to reflect on their experiences as CLCs

\footnotetext{
${ }^{48}$ The focus for this paper is on the theme of the value of community participation from the students' perspectives and these are the findings which are presented and discussed here. The feedback on the training itself and issues regarding the administration of the scheme has been used to improve the project for future cohorts.
} 
including what they had most and least enjoyed and any actual benefits. The main findings were as follows:

\section{Helping people in need and access to justice}

Interestingly, helping people in need was what the students had most enjoyed about being a CLC. Participants in the focus groups spoke passionately about how volunteering as CLCs had given them a real insight into the need in the local community for legal support and how personally rewarding they found being able to provide assistance. They also voiced frustration at the lack of support available and the difficulties LiPs face in navigating the court system.

\section{Skills development}

All the students responding felt that volunteering as CLCs had helped them develop key skills, including empathy; the ability to communicate with a range of people; and how to deal with unexpected situations. This was alongside gaining greater insight into the court process such as court forms and the various types of hearings.

\section{Employability}

Closely linked to skills development was the overwhelming feeling that their experience as CLCs would support their future employability. The students felt that the role would help them to "stand out" and be a good "talking point" at future interviews. 


\section{Supporting academic studies}

Most of the students felt that volunteering as CLCs helped to support their academic studies, particularly for those who were studying or intending to study Family Law. Many commented on how the experience had helped them make links between theory and practice and some that they could apply the professionalism needed for the role to their academic studies.

\section{Questionnaire 1:}

Table 1: Students' motivations for applying for the CLOCK scheme (some students provided more than one answer)

\begin{tabular}{|l|c|}
\hline Gain experience / employability & $54 \%$ \\
\hline Help those who really need it, the less advantaged & $51 \%$ \\
\hline Help the court system & $9 \%$ \\
\hline Personal development & \\
\hline
\end{tabular}

Table 1 shows that one of the key motivating factors for participating in the CLOCK scheme was to help the local community. Many participants considered that the CLOCK scheme would give them an opportunity to provide community support and help deliver social justice to those most in need:

"One of the main motivators behind my decision to participate in the CLOCK scheme was an attempt to help those who are in need of support and guidance." 
Figure 1: Do you think volunteering as a CLOCK CLC will support your academic studies?

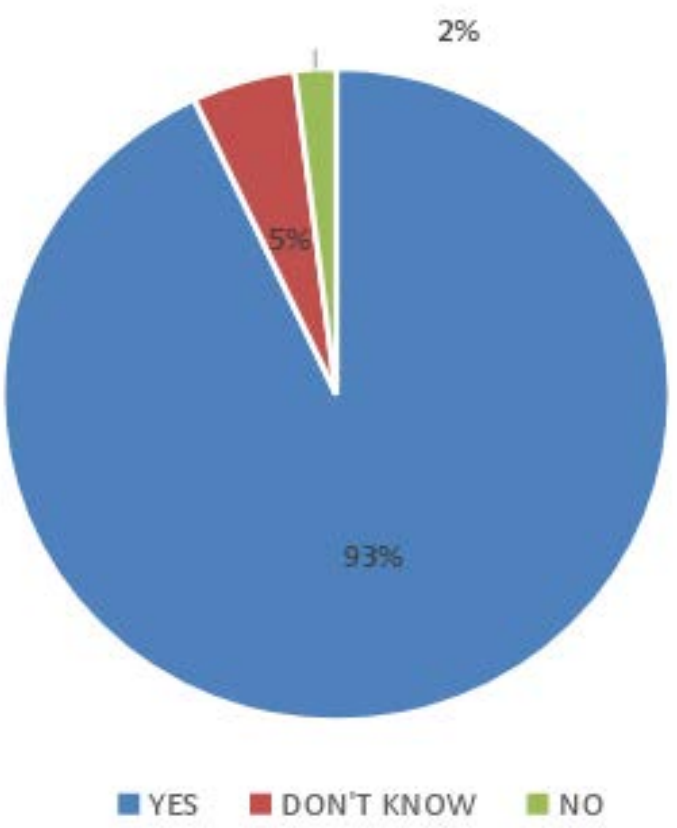

Table 2: What are your career aspirations?

\begin{tabular}{|l|c|}
\hline Solicitor (practice area not specified) & $44 \%$ \\
\hline Family lawyer & $16 \%$ \\
\hline Barrister (practice area not specified) & $14 \%$ \\
\hline Legal services & $12 \%$ \\
\hline Unsure & \\
\hline Other & $9 \%$ \\
\hline
\end{tabular}

In answer to the question about career aspirations, the answers fell into four categories; career as a solicitor, career as a barrister, uncertainty, and other career 
pathway. As noted earlier, the majority of participants when responding revealed that they intend to pursue a legal career of some kind, whilst a minority were uncertain.

The work experience opportunities presented through the CLC role were acknowledged by nearly all the participants who responded to Questionnaire 1. For instance, one participant confirmed:

"I wanted to participate because the programme seemed like a great opportunity to gain work experience while giving back to the community."

\section{Questionnaire 2:}

Table 3: What have you most enjoyed about being a CLOCK CLC?

\begin{tabular}{|l|c|}
\hline Helping people in need & $82 \%$ \\
\hline Court involvement & $12 \%$ \\
\hline $\begin{array}{l}\text { Finding out more about the legal issues people have; } \\
\text { learning about court documents; preparing myself for } \\
\text { practice; learning about the different avenues available to } \\
\text { litigants in person }\end{array}$ & \\
\hline
\end{tabular}

Assisting people in need was what most students did actually find most enjoyable once they had experienced the role as seen in Table 3. One student commented: 
"the sheer feeling you get from helping people and even just supporting them and talking them through things makes me feel like I'm making a difference (be it a cliché)."

Another reflected on the continuous learning process of being a CLC:

"it is very rewarding to be able to be a small part of making such a complicated and stressful process more transparent and manageable, especially as it reflects the area I want to work in in the future, and means I can draw from past experiences with litigants to assist future ones as well."

Figure 2: Do you think volunteering as a CLOCK CLC has supported your academic studies?

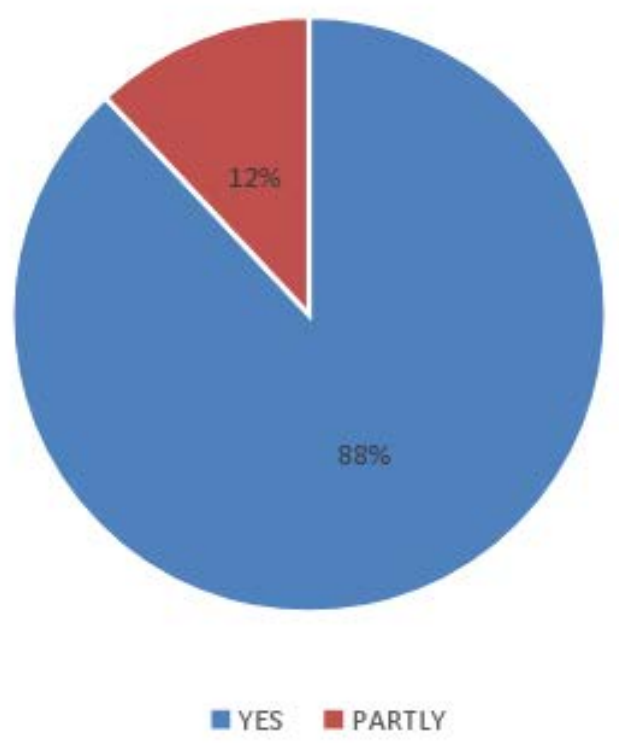

As to whether students felt volunteering as CLCs would support their academic studies, the majority felt that it would (see Figure 1) "it will allow me to see how the 
knowledge is applied in real life" and "I am wanting to study Family Law in year 3 so this matches perfectly." Again, this was borne out after experiencing the role (see Figure 2): Another noted that the experience "reinforced what I learnt in the first year on legal structures" and, "it has made me even more organised and given me a professional work ethic that I can apply to my studies." A minority of students were less sure of the role supporting their studies directly including one student who commented:

"So far, I would say it has been an additional extra, rather than a support as the areas I've assisted LIPs with have not, strictly speaking, been part of my studies. It's been a great insight into the barriers faced by those accessing the courts/justice system, or trying to."

\section{Figure 3: Do you think volunteering as a CLOCK CLC may support your future employability?}

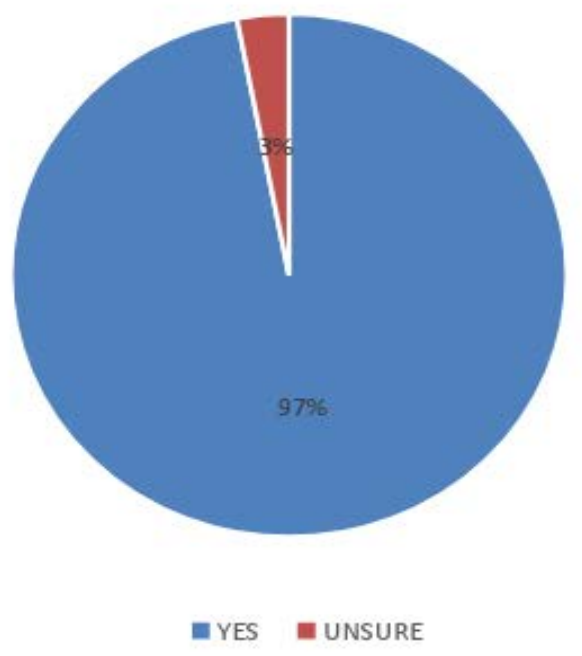

When asked specifically about employability, again students' expectations were borne out once they had carried out the role, with the vast majority (see Figure 4) stating that 
they perceived their role as a CLC would have a positive effect. Typical comments included:

"I believe that CLOCK will support my future career as a solicitor as it will help me stand out from my peers, help my experience in the legal sector and communication with individuals in difficult situations."

Standing out from the crowd in a competitive employment market was a common theme. This is in line with a research study in the USA which asked how law students could stand out and gain employment in a public interest legal job. The responses revealed that employers "value practical experience" and advise students to "[e]nroll in a clinical education programme" ${ }^{49}$

Development of key skills was an emerging theme from Questionnaire 2. All CLCs felt that participating in the scheme had helped them develop key skills. These included empathy; dealing with people; time management; professionalism; communication skills; listening skills; and coping well under pressure. As noted earlier when considering the employability value of the scheme some students considered that "every aspect of [the skills acquired as a CLC are] transferable".

The key themes of helping in the wider community, impact on academic studies and employability were further explored in the focus groups. University of Brighton

\footnotetext{
${ }^{49}$ National Association for Law Placement, NALP Public Interest Employment Market Snapshot Report 3, 16 (2012) in Kuehn, R. R. supra, note 33 p.661.
} 
students talked about the difficulties for often vulnerable people who are "lost in the system". One said "we are a bridge, someone to talk to", another "court is so daunting". ${ }^{50}$ What emerged from the groups was an appreciation of the difficulties that litigants in person face when trying to access the court system. It was also clear that students had reflected deeply on their experiences, with one commenting that "[CLOCK has] changed the way you look at people." Another, who had assisted a litigant who had recently served a prison sentence, said that CLOCK had helped her to overcome her own prejudices, saying "there's more to people than a stereotype". A recurring thread of the discussion was that they felt they were a link/bridge, particularly as in the Brighton Family Court, where they are based, what was the public counter, is now closed as a result of cuts to court funding.

Exploring further the question of whether volunteering as CLCs supported their academic studies, a common feeling was that it had helped them "to piece things together." 51 For some of them, being part of the CLOCK project had shaped their future academic choices, one said that participating "made me want to do Family Law. I had no interest in Family Law before." Another said that they were planning to take the

\footnotetext{
${ }^{50}$ The views of the students correlate with the findings of the Law Society's review 'Access Denied? LASPO 4 years on: A Law Society Review, available at: http://www.lawsociety.org.uk/supportservices/research-trends/laspo-4-years-on/ (accessed on 03.07.17).

${ }^{51}$ This is in line with Maranville, D. A's view that "[C]ontext helps students understand what they are learning, provides anchor points so they can recall what they learn, and shows them how to transfer what they learn in the classroom to lawyers' tasks in practice." 'Infusing Passion and Context into the Traditional Curriculum through Experiential Learning', Journal of Legal Education, Volume 51, No.1 (March 2001) p.52.
} 
Innocence Project module as a final year elective so that they could explore access to justice further. All of the Brighton focus group participants felt that the experience had helped them to be more organised and had added meaning to their academic work, whatever the area. One student noted that having CLOCK as part of a module "would be incredibly useful." 52

There was evidence from the responses that students like the 'reality' of the experience. In support of the 'real life' experience which they are exposed to one participant said:

"I think it will provide me with valuable experience in terms of what to expect when it comes to dealing with real life disputes as well as understanding the legal environment."

This supports a point that Kerrigan and Murray make when they say that clinical legal education requires participation in the legal system. ${ }^{53}$ Another participant commented that at a networking event a lawyer had told her that every day is different and she felt that CLOCK had brought that home to her "this is a real-life job" and "the more you do it, the more you enjoy it." Regarding development, dealing with people/communication skills was the most discussed skill, but participants also

\footnotetext{
${ }^{52}$ At some of the participating universities, including the University of Sussex, students can volunteer as CLCs as the practical element of a clinical legal education module and this is something that both the University of Brighton and Canterbury Christ Church University are looking to develop.

${ }^{53}$ Kerrigan, K., \& Murray, V. (2011). A Student Guide to Legal Education and Pro Bono. Palgrave Macmillan, pp.6-7.
} 
reflected on the need to be professional in terms of time-keeping, organisation, dress and keeping a professional distance, all of which they felt would help them in terms of employability. There was a broad acceptance that participating as a CLC would be an opportunity to enhance their CVs. Participants also talked about developing professional networks with court staff, lawyers they meet at court and the CLOCK partners, which they felt confident would assist with future employability.

The broader research, which is being conducted by a team of CLOCK researchers nationally, considers the value of collaborative frameworks to support social and legal policy research and to monitor and critically analyse legal issues in the local community towards wider dissemination, social advocacy and policy reforms at local, national and international level. Our strong impression is that CLCs feel part of the wider context of access to justice and we were pleased to see their contribution recognised nationally at the LawWorks and Attorney General Student Awards 2016.54

\section{CHALLENGES OF ESTABLISHING THE SCHEME}

Establishing such a scheme is not without its challenges though. At both Canterbury and Brighton it was necessary to take the lead on outreach into the local community to explore the possibility of stakeholder support. It was the responsibility of academic

\footnotetext{
54 For further details about the LawWorks and Attorney General Student Awards 2016 see: https://www.lawworks.org.uk/solicitors-and-volunteers/get-involved/lawworks-attorney-generalstudent-awards-2016 (accessed on 10.07.17).
} 
leads within the institutions involved to encourage members of the legal services community, third sector advice services, HM Court \& Tribunal Service, to support the initiative. Whilst this was initially quite a challenging undertaking (albeit very much supported by members of the regional judiciary), it was soon evident that there was enthusiasm and support for the introduction of the scheme in both areas of the country. Indeed, as the scheme became more widely known, both Brighton and Canterbury were approached by a number of legal service providers wanting to come on board. It was also necessary to publicise the service through the universities' marketing channels and organise promotional material to distribute to various local community hubs, including MPs' constituency offices to raise awareness of the service.

Some of the additional practical challenges are those familiar to anyone running extracurricular activities, such as recruiting sufficient numbers of students, securing training rooms and any other necessary resources. Brighton does not have dedicated administrative support and therefore decided to appoint a Student Liaison from both Brighton and Sussex to assist with aspects such as publicising rota gaps, forthcoming hearings for which a CLC has been requested and to manage the email service. It is important that the scheme runs as effectively as possible and ongoing dialogue with the CLCs, partners and court staff is maintained, so that the service can be improved. 
Brighton is in the process of developing shadowing opportunities for their CLCs with the partners, with a view to facilitating increased understanding of their services..$^{55}$

Given that this is a public-facing role, it is essential that students are fully committed to the project and fulfil their obligations to the initiative as well as to their fellow CLCs. ${ }^{56}$ It is also essential to ensure CLCs feel supported, particularly given that there is no direct academic supervision of court desk activities. Close communication with the academic leads is essential and we also recommend input during the training week from student support services so that CLCs are aware of the wider pastoral support available to them should they find a particular case distressing.

To coordinate the scheme, it was considered necessary to form a steering group to support the Kent project. The CLOCK in Kent Steering Group comprises student CLCs, representatives from local advice and assistance services, law firms, the judiciary and the court service. The role of the steering committee is to provide support, advice and guidance to the CLOCK in Kent project to ensure that the project operates effectively and is a sustainable and viable initiative. Quarterly meetings of the steering group have been organised and these have been well attended so far.

\footnotetext{
55 To date CAFCASS and two of Brighton's practitioner partners have provided shadowing opportunities for our CLCs.

${ }^{56}$ At the University of Brighton for our first cohort we asked students to submit an application letter, outlining why they would like to participate in CLOCK. For our second cohort we followed the same process but with an additional short interview.
} 
Training of the CLCs requires the support, supervision and coordination of academic and support staff members as well as representatives of the local partner organisations. The training programme needs to be designed with local community need in mind but broadly will include the use of local legal practitioners to provide guidance on court applications and procedure, local mediators to provide awareness and guidance on mediation referral, third sector agencies to provide awareness of local provision including domestic violence and housing advice and court staff to provide guidance on the court process.

\section{CONCLUSION}

CLOCK has provided an opportunity to introduce clinical legal education to a number of UK law schools, or in other words, enable students to learn by 'doing', alongside the curriculum. Clinical legal education is intended to produce students that can take the learning experience offered by live clinics and reflect upon how and why cases were progressed and how this fits into the overall context of their legal studies. ${ }^{57}$ Such approaches intend to empower students to become pro-active learners and to provide formative assessment methods, which are in themselves are a strategic and integral part of the learning experience. The CLOCK project proposes to achieve all these

\footnotetext{
${ }^{57}$ See Ibid, Murray, V. pp. 226-249, for helpful analysis of Schön's established approaches to reflection (reflection on action and in action), and Greenaway, Boud, Gibbs \& Kolb for models of reflection.
} 
aspirations and there are opportunities to introduce summative credit based assessment, which can provide students with academic credit for their involvement. ${ }^{58}$

The benefits of participating in CLOCK from the perspectives of legal education and employability can also be viewed in conjunction with the requirements for law graduates as per the QAA Subject Benchmark for Law 2015, ${ }^{59}$ which highlights among other requirements, the need for communication skills. It is also likely that the skills developed through the CLOCK scheme will become even more crucial as legal education providers transition to the Solicitors Qualifying Exam, which has an emphasis on key legal skills in Stage 2. ${ }^{60}$

Law students' experience is undoubtedly enhanced through the establishment of regional versions of CLOCK and the Community Legal Companion scheme. The advantages of such a project are self-evident. It assists the community, it facilitates potential mediation referrals for local mediation services (through agency signposting), it provides employability opportunities for students through personal professional development/CV enhancement, and gives them a sense of responsibility, independence of thought and achievement through community/public spirited social

\footnotetext{
${ }^{58}$ Ibid pp. 250-268, for some ideas on assessment methods for such clinical legal education projects.

59 QAA Subject Benchmark Statement: Law July 2015 UK quality Code for Higher Education Part A: Setting and maintaining academic standards: http://www.qaa.ac.uk/en/Publications/Documents/SBSLaw-15.pdf (accessed 10.01.17).

${ }^{60}$ Supra, note 30.
} 
justice engagement, as well as enabling an appreciation of legal ethics. ${ }^{61}$ Particularly given the overwhelming social justice motivations for participating discussed earlier, further longitudinal research would be interesting to explore the impact of volunteering for CLOCK as the CLCs graduate and progress in their careers, considering inter alia, whether there is an increased likelihood of them pursuing roles in areas more typically associated with social justice and whether they are more likely to engage in pro bono work than peers who have not participated in such a scheme, as a result. ${ }^{62}$

${ }^{61}$ See generally; Bloch, F. S. (ed.) (2011) The Global Clinical Movement: Educating Lawyers for Social Justice, (New York: Oxford University Press); Baron, P. \& Corbin, L. (2012). Thinking like a lawyer/acting like a professional: Communities of practice as a means of challenging orthodox legal education. The Law Teacher, 46(2), 100-119." 46(2); A. Francis, "Legal Education, Social Mobility, and Employability: Possible Selves, Curriculum Intervention, and the Role of Legal Work Experience." Journal of Law and Society 42.2 (2015): 173-201.

${ }^{62}$ See e.g. McKeown, P., 'Pro Bono: What's in it for Law Students? The students' Perspective', International Journal of Clinical Legal Education, Vol 24, No 2 (2017) pp 43-80 which explores students' motivations for participating in pro bono work and considers whether this is likely to instil a public service ethos which they will carry forward. 